\title{
Organic Carbon Decomposition in Soil Amended With Organic Compost From Slaughterhouse Residues
}

\author{
Magnum de Sousa Pereira ${ }^{1}$, Julius Blum ${ }^{1}$, Henrique Antunes de Souza ${ }^{2} \&$ Carlos Kenji Taniguchi $^{3}$ \\ ${ }^{1}$ Departamento de Ciências do Solo, Federal University of Ceará, Fortaleza, Ceara, Brazil \\ ${ }^{2}$ Brazilian Agricultural Research Corporation-Embrapa Goats and Sheep, Sobral, Ceara, Brazil \\ ${ }^{3}$ Brazilian Agricultural Research Corporation-Embrapa Tropical Agroindustry, Fortaleza, Ceara, Brazil \\ Correspondence: Julius Blum, Departamento de Ciências do Solo, Federal University of Ceará, Campus do Pici, \\ BL. 807-Av. Mister Hull, s/n-Pici, Fortaleza, Ceará 60455-760, Brazil. Tel: 55-85-3366-9209. Fax: \\ 55-85-3366-9690. E-mail address: jblum@ufc.br
}

Received: April 6, 2018

doi:10.5539/jas.v10n8p7

\author{
Accepted: May 18, $2018 \quad$ Online Published: July 15, 2018 \\ URL: https://doi.org/10.5539/jas.v10n8p7
}

\begin{abstract}
Decomposition kinetic of applied compost in soil depends on the decomposition rate coefficient (k), environmental conditions and the interactions with soil. However, studies with the aim of determining $\mathrm{k}$ values for different materials rarely consider interactions with soil. The objective of the current study was to estimate $\mathrm{k}$ value of an organic compost, considering the interactions with the soil. Samples of soil mixed with compost were incubated in hermetic recipients for 126 days and evolved $\mathrm{C}_{-} \mathrm{CO}_{2}$ was quantified. Nonlinear models proposed in the present study were fitted to evolved $\mathrm{C}-\mathrm{CO}_{2}$ data. Better fitting was found in a model that divided the soil organic matter in four pools (labile and recalcitrant native soil organic matter; protected and unprotected added organic matter), values of $\mathrm{k}$ on both native organic matter pools were multiplied by a constant denominated priming (pr) only in the cases where the compost was added to the soil and the amount of $\mathrm{C}$ in the protected pool is limited to the soil protection capacity. Organic compost produced using carcasses, sheepfold residues and slaughterhouse residues presented $\mathrm{k}$ value equal to $0.01179 \mathrm{day}^{-1}$ at $31{ }^{\circ} \mathrm{C}$ without water stress. Compost application increased in $9.8 \%$ the decomposition of the native soil organic matter.
\end{abstract}

Keywords: carbon protection, decomposition model, priming effect, soil organic carbon

\section{Introduction}

Organic composts are used since ancient times in agriculture to fertilize and improve physical, chemical and biological soil properties (Blum, 1992). Composting consist in the transformation of fresh organic residues into more stable organic material, which is advantageous compared to the application of fresh organic materials (Zhang et al., 2012). Among these advantages, could be featured: (i) Volume reduction, facilitating the storage and transport; (ii) stabilization and homogenization allowing storage, management and scheduling of its use as fertilizer (Orrico, Lucas Júnior, \& Orrico Júnior, 2007); (iii) Pests and pathogens elimination due to the high temperatures (over $60{ }^{\circ} \mathrm{C}$ ) reached during the composting process (Noble \& Roberts, 2004).

In spite of its ancient use, the technology for application of organic compost in soil can still be improved. The knowledge of the decomposition kinetics of compost in soil allows the establishment of a correct dosage and scheduling application. This planning aims the maintenance of soil organic carbon and the correct supply of nutrients, avoiding contamination and soil degradation. Kinetic of organic matter material is largely dependent on the decomposition rate coefficient $(\mathrm{k})$. The $\mathrm{k}$ value is specific to each material, depending on its composition, mainly: nitrogen, sugars, protein, cellulose, hemicelluloses, lignin (Garcia-Pausas, Casals, Camarero, Huguet, Thompsone, Sebastia, \& Romanya, 2008; Hébert, Karam, \& Parent, 1991; Jin, Haney, Fay, \& Polley., 2013).

An increasing attention has been directed to the use of residues generated throughout the food system, aiming at the nutrient cycling (Lehmann, 2013). Alternative uses for a large range of residues have been studied, including composting of carcasses and slaughterhouse residues (Berge, Glanville, Millner, \& Klingborg, 2009). Use of this organic compost, as fertilizer in agricultural land, allows nutrient cycling, however, the use of different materials produces composts with equally variable characteristics, demanding additional studies to its characterization, including the determination of the $\mathrm{k}$ value. 
Besides $\mathrm{k}$ value, the decomposition rate of organic compost in the soil depends on temperature, moisture and its interactions with the soil matrix and the native soil organic matter. Moisture and temperature are factors that are easily measured or controlled in experimental sets. Thus, the $\mathrm{k}$ value obtained experimentally can be adjusted to real conditions according to the models proposed by van Veen and Paul (1981), Jenkinson, Andrew, Lynch, Goss and Tinker (1990) or Kätterer, Reichstein, Andrén and Lomander (1998). However, interactions of applied organic matter with soil are rarely explored. Not considering these interactions, the $\mathrm{k}$ value obtained experimentally is restricted only to the soil used in the experimental set, severely limiting its practical utilization.

Priming effect and organic matter protection by soil matrix are the main interactions that occur after compost is added into the soil. Priming effect is a stimulus to microbial activity by the addition of other source of organic matter (Waldrop \& Firestone, 2004). This stimulus increases the decomposition rate of the native organic matter (Kuzyakov, Friedel, \& Stahr, 2000). On the other hand, organic matter can be protected in soil matrix by result of the adsorption of organic matter on soil colloids or aggregate formation, resulting physical protection against microbial decomposition (Six, Conant, Paul, \& Paustian, 2002). Priming effect and the organic matter protection depends on soil and native organic matter properties, including aspects related to texture and mineralogy.

The objective of the current study was to estimate the $\mathrm{k}$ value of organic compost, applying a model that considers soil matrix protection and priming effect. Using for this purpose organic compost produced using carcasses, sheepfold residues and slaughterhouse residues.

\section{Material and Methods}

The decomposition rate coefficient was obtained by organic compost incubation in soil from $0-0.20 \mathrm{~m}$ depth. The soil was taken from a typical Ortic Chromic Luvisol under agroforest system used to raise sheep and goats, located at the city of Sobral, Ceará state, Brazil $\left(3^{\circ} 40^{\prime} 07.0^{\prime \prime} \mathrm{S}\right.$ and $\left.40^{\circ} 29^{\prime} 04.9^{\prime \prime} \mathrm{W}\right)$. Soil collection was done at a single point using a shovel, ensuring homogeneous representavity in depth. Soil analysis presented: $\mathrm{pH}\left(\mathrm{CaCl}_{2}\right)=$ 6.5; $\mathrm{Ca}^{2+}, \mathrm{Mg}^{2+}, \mathrm{Al}^{3+}, \mathrm{H}+\mathrm{Al}, \mathrm{K}^{+}$and $\mathrm{Na}^{+}$equal to $96.0,34.0,1.0,30.0,9.1,2.8$ mmol $_{\mathrm{c}} \mathrm{kg}^{-1}$, respectively; $\mathrm{CEC}=$ $171.9 \mathrm{mmol}_{\mathrm{c}} \mathrm{kg}^{-1}$; BS equal to $82.6 \%$, Total organic carbon (TOC) equal to $13.2 \mathrm{~g} \mathrm{~kg}^{-1}$; Total-N equal to $0.84 \mathrm{~g}$ $\mathrm{kg}^{-1}$; bulk density equal to $1.41 \mathrm{~g} \mathrm{~cm}^{-3}$; sand, silt and clay equal to $648.0,247.4$ and $104.6 \mathrm{~g} \mathrm{~kg}^{-1}$ respectively. $\mathrm{Ca}^{2+}$ and $\mathrm{Mg}^{2+}$ were extracted with $1 \mathrm{~mol} \mathrm{~L}^{-1} \mathrm{KCl}$ solution and quantified by atomic absoption spectrofotometry. Total $\mathrm{N}$ was mesured by semimicro Kjedhal method and sulfuric digestion. $\mathrm{P}, \mathrm{K}^{+}$and $\mathrm{Na}^{+}$were measured in Mehlich 1 extracts. $\mathrm{H}+\mathrm{Al}$ was measured by titration with $\mathrm{NaOH}$ solution in calcium acetate extracts. Total organic carbon was measured by Walkley-Black method.

Organic compost was produced in a rain protected compartment encompassed with wood boards ( $3.5 \mathrm{~m}$ long, 2.0 $\mathrm{m}$ width and $1.6 \mathrm{~m}$ high). The raw materials were deposited in $0.3 \mathrm{~m}$ layers: a layer of slaughterhouse residues or dead sheep or goats were sandwiched between layers of sheepfold manure mixed with sheepfold food waste (1:1 proportion). Water was added only during the layers' deposition, using the equivalent to $40 \%$ of the weight of slaughterhouse residues or dead sheep or goats in water. These layers were successively piled up until reaching the maximum compartment high and kept without mixing until compost stabilization, in approximately 120 days. Aeration was kept by convection, since the air could pass through the openings between wood boards. The openings between the wood boards are approximately $2 \mathrm{~cm}$ wide

Organic compost samples were taken after the stabilization, from different depths and locations along the pile, ensuring a representative sample. Chemical characteristics obtained following Abreu, Andrade, and Falcão (2006) procedures showed: 136.7, 20.3, 9.0, 15.7, 21.9, 5.5 and $2.8 \mathrm{~g} \mathrm{~kg}^{-1}$ of C, N, P, K, Ca, Mg and S, respectively; 20, $30,2051,175$ and $138 \mathrm{mg} \mathrm{kg}^{-1}$ of $\mathrm{B}, \mathrm{Cu}, \mathrm{Fe}, \mathrm{Mn}$ and $\mathrm{Zn}$, respectively; $\mathrm{pH}$ value of 6.7.

Before the incubation, soil and organic compost were were individually air dried and sieved through $2 \mathrm{~mm}$ opening and exhaustively homogenized. The incubation was performed in $2 \mathrm{~L}$ hermetic glass recipients with 141 $\mathrm{g}\left(100 \mathrm{~cm}^{3}\right)$ soil samples mixed with doses of compost, equivalent to $0 ; 0.182 ; 0.363 ; 0.727$ and $1.454 \mathrm{~g} \mathrm{~kg}^{-1}$ of C. These rates are equivalents to $0,0.5,1,2$ and 4-fold the standard dose of $7.5 \mathrm{Mg} \mathrm{ha}^{-1}$ of compost, considering the $0.2 \mathrm{~m}$ soil layer and soil density of $1.41 \mathrm{~g} \mathrm{dm}^{-3}$. The standard dose of $7.5 \mathrm{Mg} \mathrm{ha}^{-1}$ of compost was calculated based in the regional nitrogen fertilizer recommendation for corn yield of $8 \mathrm{Mg} \mathrm{ha}^{-1}$ (Alves et al., 1999) and the total $\mathrm{N}$ concentration in compost. The soil $\mathrm{pH}$ value was corrected to 7 , based in $\mathrm{CaCO}_{3}$ neutralization curves, previously fitted for each dose of compost.

The containers were distributed in a completely randomized design with three replicates per treatment and arranged in split plot in time scheme. Carbon dioxide evaluation was performed at $0 ; 1 ; 2 ; 3 ; 4 ; 5 ; 6 ; 7 ; 9 ; 11 ; 14 ; 17$; $20 ; 23 ; 26 ; 29 ; 33 ; 37 ; 41 ; 48 ; 55 ; 69 ; 83 ; 97 ; 111$ and 126 days of incubation. Carbon dioxide was trapped in 0.5 mol L ${ }^{-1} \mathrm{NaOH}$ solution and quantified by titration with $0.25 \mathrm{~mol} \mathrm{~L}^{-1} \mathrm{HCl}$ solution. 
Value of $\mathrm{k}$ was fitted using carbon evolved as carbon dioxide $\left(\mathrm{C}-\mathrm{CO}_{2}\right)$ from treated soil, considering two situations: without and with interaction of added organic matter with soil matrix and native soil organic matter. Considering absence of interaction, the mineralized $C$ from the organic compost $\left(\mathrm{C}_{\mathrm{mc}}\right)$ was obtained by difference between $\mathrm{C}-\mathrm{CO}_{2}$ evolved from samples incubated without $\left(\mathrm{C}_{\mathrm{m} \text { soil }}\right)$ and with compost $\left(\mathrm{C}_{\mathrm{m} \text { soiltcompost }}\right)$ (Equation1). The $\mathrm{k}$ value was estimated iteratively considering a simple exponential model proposed by Olson (1963) (Equation 2).

$$
\begin{gathered}
C_{m c}=C_{m \text { soiltcompost }}-C_{m \text { soil }} \\
C_{m c}=C_{0}\left(1-e^{-k t}\right)
\end{gathered}
$$

Where, $\mathrm{C}_{\mathrm{mc}}=\mathrm{C}-\mathrm{CO}_{2}$ evolved from compost, $\mathrm{g} \mathrm{kg}^{-1} ; \mathrm{C}_{0}=$ carbon added as compost, $\mathrm{g} \mathrm{kg}^{-1} ; \mathrm{k}=$ decomposition rate coefficient of the organic compost, day ${ }^{-1}$ and $\mathrm{t}=$ time, days.

In case of interaction, the $\mathrm{C}-\mathrm{CO}_{2}$ evolved from the compost and the $\mathrm{k}$ values were estimated considering the models proposed in the present study. These models will be presented and more detailed explained at the results and discussion section. Proposed models were developed based in the double exponential model proposed by Lousier and Parkinson (1976) (Equation 3) added by coefficients related with priming effect and organic matter protection.

$$
C_{m}=C_{a}\left(1-e^{-k_{1} t}\right)+C_{b}\left(1-e^{-k_{2} t}\right)
$$

Where, $\mathrm{C}_{\mathrm{m}}=$ mineralized $\mathrm{C}-\mathrm{CO}_{2}, \mathrm{~g} \mathrm{~kg}^{-1} ; \mathrm{C}_{\mathrm{a}}=$ carbon content in the first organic matter pool, $\mathrm{g} \mathrm{kg}^{-1} ; \mathrm{C}_{\mathrm{b}}=$ carbon content in the second organic matter pool, $\mathrm{g} \mathrm{kg}^{-1} ; \mathrm{k}_{1}=$ decomposition rate coefficient of the first organic matter pool, day ${ }^{-1} ; \mathrm{k}_{2}=$ decomposition rate coefficient of the second organic matter pool, day ${ }^{-1}$ and $\mathrm{t}=\mathrm{time}$, days.

Fitting of non-linear models to the data were performed by iterative processes through Newton method, minimizing the sum of deviation between estimated and measured values using proc nlin of SAS software. The sum of soil $\mathrm{C}$ pools was limited to the total $\mathrm{C}$ content of soil + compost.

Mineralized fraction (MF) is the fraction of added $\mathrm{C}$ evolved as $\mathrm{C}-\mathrm{CO}_{2}$. The MF, expressed in percentage of the added organic matter, was calculated using the Equation (4).

$$
M F=\left(X_{C O y}-X_{C O 0}\right) / Q_{a d d e d} \times 100
$$

Where, $\mathrm{X}_{\mathrm{COy}}=\mathrm{C}-\mathrm{CO}_{2}$ evolved from the treatment with the dose $\mathrm{y}$ of organic compost, $\mathrm{g} \mathrm{kg}^{-1} ; \mathrm{X}_{\mathrm{CO} 0}=\mathrm{C}-\mathrm{CO}_{2}$ evolved from the control treatment, $\mathrm{g} \mathrm{kg}^{-1} ; \mathrm{Q}_{\text {added }}=$ Carbon added as organic compost, $\mathrm{g} \mathrm{kg}^{-1}$.

\section{Results and Discussion}

The first approach to describe the degradation kinetics of carbon from compost in soil considered independence between carbon added and native soil organic carbon. Cumulative exceeding $\mathrm{C}-\mathrm{CO}_{2}$ evolution in relation to control treatment presented exponential growth (Figure 1). Reduction of daily rate emission through the time is frequently observed and is explained by substrate and nutrient depletion due to microbe consumption (Cayuela, Sinicco, \& Mondini, 2009; Demetz \& Insam, 1999; Fangueiro, Ribeiro, Vasconcelos, Coutinho, \& Cabral, 2012). A simple exponential model was fitted to the exceeding $\mathrm{C}-\mathrm{CO}_{2}$ emission data, obtaining $\mathrm{k}$ values with a variation inversely proportional to the applied compost dose (Table 1). However, since the $\mathrm{k}$ value is function of the material composition, it is specific to each material (Berg \& McClaugherty, 2008). Thus, the $\mathrm{k}$ value should not vary due to the applied dosage. The occurrence of this variability indicates the existence of interaction between applied organic material and soil matrix or with native soil organic matter, evidencing the necessity of including these variables in the carbon decomposition model. 


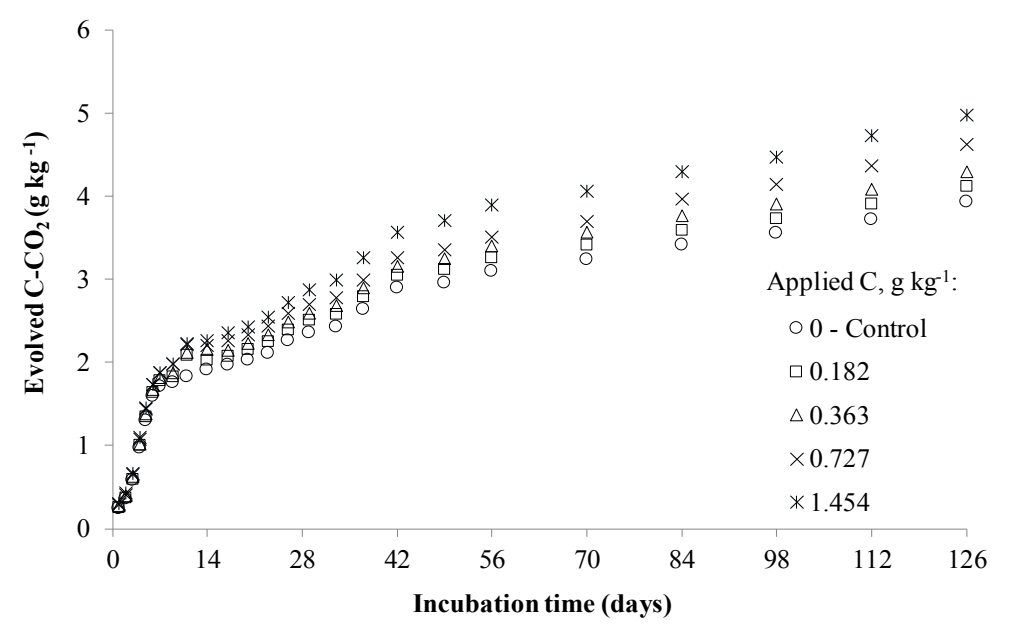

Figure 1. Cumulative $\mathrm{C}-\mathrm{CO}_{2}$ emission measured in soil samples amended with compost. Data are means $(\mathrm{n}=3)$

Table 1. Fitting parameters of a simple exponential model $\left(C_{m c}=C_{0}\left(1-e^{-k t}\right)\right.$ applied to cumulative $\mathrm{C}-\mathrm{CO}_{2}$ emission, calculated by the difference between $\mathrm{C}-\mathrm{CO}_{2}$ measured in soil samples amended with compost and control

\begin{tabular}{llllll}
\hline Treatment & $\mathrm{C}-$ Compost $\left(\mathrm{C}_{0}\right)$ & $\mathrm{k}$ & $\mathrm{P}$ & $\mathrm{R}^{2}$ & $\mathrm{MF}$ \\
\hline & $\mathrm{g} \mathrm{kg}^{-1}$ & day $^{-1}$ & & & $\%$ \\
1 & 0.182 & 0.0570 & $<0.0001$ & 0.989 & 98.3 \\
2 & 0.363 & 0.0371 & $<0.0001$ & 0.993 & 99.1 \\
3 & 0.727 & 0.0203 & $<0.0001$ & 0.943 & 95.0 \\
4 & 1.454 & 0.0131 & $<0.0001$ & 0.979 & 71.5 \\
\hline
\end{tabular}

Note. $\mathrm{C}_{\mathrm{mc}}=$ Mineralized carbon from compost; $\mathrm{C}_{0}=$ Carbon added as compost; $\mathrm{k}=$ decomposition rate coefficient of the organic compost; $\mathrm{MF}=$ Mineralized fraction.

Two diverting interactions can be expected between added organic material and soil: (i) reduction of decomposition rate due to protection of added organic material by soil matrix; (ii) increase of decomposition rate due to priming effect. The decrease of $\mathrm{k}$ values observed with increase of compost dosage at the present study contradict the protection mechanism theory. Protection mechanism described by Six et al. (2002) assume that the soil has limited protection capacity. High dosages would surpass the protection capacity of the soil, sharing the added organic material into two pools: protected and unprotected against microbial decomposition. Therefore, the greater the amount applied, the greater will be the share of the unprotected pool. Thus, higher rate of decomposition at higher dosages would be expected.

Mineralized fraction (MF) higher than $100 \%$ is a clear-cut evidence of priming effect, indicating carbon consumption larger than added (Blagodatskaya \& Kuzyakov, 2008). In the present research, MF was $98 \%$ at lower dosage and $72 \%$ at higher dosage of organic compost (Table 1). Despite of the fact that priming effect is not confirmed in this case, the occurrence of priming effect is a hypothesis that cannot be discarded: applied organic material could stimulate the decomposition rate of native organic matter; however, the amount of organic material applied could replace all the organic matter decomposed due to this stimulation (Shen \& Bartha, 1996).

The mineralization rates presented at table 1 were calculated based on the difference between the $\mathrm{C}-\mathrm{CO}_{2}$ evolved from soil treated with organic compost and control treatment. In this case it is necessary to assume the absence of interaction between added organic material and native soil organic matter. However, in the case of the occurrence of priming effect, the additional fraction of $\mathrm{C}-\mathrm{CO}_{2}$ evolved from the native organic matter due to the priming effect is accounted as $\mathrm{C}-\mathrm{CO}_{2}$ evolved from added organic material. This will overestimate the $\mathrm{k}$ value of the added organic material. Assuming that the $\mathrm{k}$ value of applied organic material does not vary due to applied dosage; overestimation will be proportionally higher at lower dosages. Explaining by this hypothesis estimated k values are inversely proportional to applied dosages. Once again, suggesting that the determination of the $\mathrm{k}$ value through the difference between $\mathrm{C}-\mathrm{CO}_{2}$ evolved from soil treated with organic compost and control treatment is not correct. 
Real source of extra evolved C can only be confirmed using labeled organic matter (Blagodatskaya \& Kuzyakov, 2008). However, since the labeling of the organic compost was not possible, a model that considers the priming effect and the soil matrix protection was employed to estimate $\mathrm{k}$ value considering the interactions with soil. A priming effect model was proposed by Kuzyakov et al. (2000); they suggested that a part (pe) of the recalcitrant native soil organic matter will be converted to labile organic matter. This portion will decompose at the same rate $\left(\mathrm{k}_{\mathrm{c}}\right)$ as the added organic material $\left(\mathrm{C}_{\mathrm{c}}\right)$ (Equation 5). The authors pointed out that the size of the portion pe is function of the added amount of organic material $\left(\mathrm{C}_{\mathrm{c}}\right)$, thus, $p e$ is fraction $p$ of $\mathrm{C}_{\mathrm{c}}$ (Equation 6). Soil matrix protection was modeled following the propositions of Six et al. (2002): the amount of added organic compost that will be protected is limited by the maximum protection capacity of the soil. Thus, if the added organic material exceeds this limit, it will be shared between two pools: protected $\left(\mathrm{C}_{\mathrm{pc}}\right)$ and unprotected $\left(\mathrm{C}_{\mathrm{uc}}\right)$ added compost. The employment of a double exponential model to describe the decomposition kinetics of the native soil organic matter is justified due to its different degrees of stabilization at a range of environmental conditions (Bernal \& Kirchmann, 1992; Boyle \& Paul, 1989; Marstorp \& Kirchmann, 1991). Presence of pools of organic matter with different decomposition rates is visualized at $\mathrm{C}-\mathrm{CO}_{2}$ evolution curves (Figure 2). A complete model is suggested in in the present study following the propositions of the above-mentioned authors (Equation 7).

$$
\begin{gathered}
C_{e}=\left(C_{c}-p e\right) \times\left(1-e^{-k_{c} t}\right) \\
p e=p \times C_{c} \\
C_{o}=C_{l s} e^{-k_{s s} t}+\left(C_{r s}-p e\right) e^{-k_{s s} t}+C_{p c} e^{-k_{p c} t}+\left(C_{d c}+p e\right) e^{-k_{d c} t}
\end{gathered}
$$

Where, $\mathrm{C}_{\mathrm{e}}=\mathrm{C}-\mathrm{CO}_{2}$ evolved due to addition of organic material, $\mathrm{g} \mathrm{kg}^{-1} ; \mathrm{C}_{\mathrm{c}}=$ Carbon from organic compost, $\mathrm{g}$ $\mathrm{kg}^{-1} ; \mathrm{C}_{\mathrm{o}}=$ total residual soil organic carbon, $\mathrm{g} \mathrm{kg}^{-1} ; \mathrm{kc}=$ decomposition rate coefficient of compost added $\mathrm{C} ; \mathrm{p}=$ fraction of recalcitrant native $\mathrm{C}$ converted to labile $\mathrm{C} ; \mathrm{C}_{\mathrm{ls}}=$ Native Soil $\mathrm{C}\left(\mathrm{g} \mathrm{kg}^{-1}\right) ; \mathrm{k}_{\mathrm{ls}}=$ decomposition rate coefficient of Native Soil $\mathrm{C}\left(\mathrm{day}^{-1}\right) ; \mathrm{t}=$ time (days); $\mathrm{C}_{\mathrm{rs}}=$ recalcitrant native soil $\mathrm{C}\left(\mathrm{g} \mathrm{kg}^{-1}\right)$; pe = mass of recalcitrant native $\mathrm{C}$ converted to labile $\mathrm{C}\left(\mathrm{g} \mathrm{kg}^{-1}\right) ; \mathrm{k}_{\mathrm{rs}}$ decomposition rate coefficient of recalcitrant native soil $\mathrm{C}$ $\left(\right.$ day $\left.^{-1}\right) ; \mathrm{C}_{\mathrm{pc}}=$ protected added $\mathrm{C}\left(\mathrm{g} \mathrm{kg}^{-1}\right) ; \mathrm{k}_{\mathrm{pc}}=$ decomposition rate coefficient of protected added $\mathrm{C}\left(\mathrm{day}^{-1}\right) ; \mathrm{C}_{\mathrm{uc}}=$ Unprotected added $\mathrm{C}\left(\mathrm{g} \mathrm{kg}^{-1}\right) ; \mathrm{k}_{\mathrm{dc}}=$ decomposition rate coefficient of Unprotected added $\mathrm{C}\left(\right.$ day $\left.^{-1}\right)$.

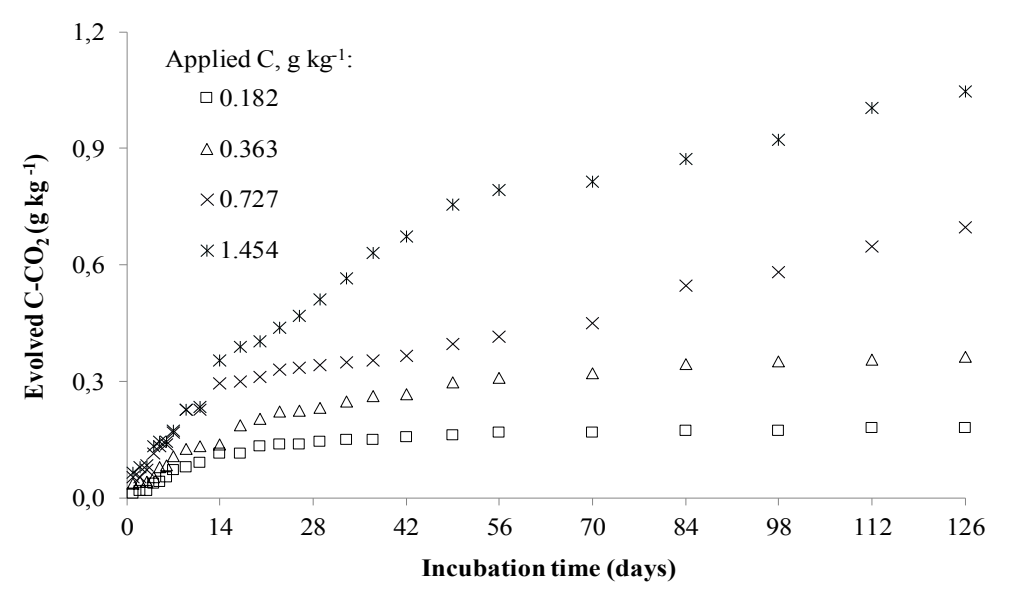

Figure 2. Cumulative $\mathrm{C}-\mathrm{CO}_{2}$ emission calculated by the difference between $\mathrm{C}-\mathrm{CO}_{2}$ measured in soil samples amended with compost and control. Data are means $(n=3)$

However, as previously discussed, the interpretation of Table 1 suggests that the priming effect is constant, independent of the applied dose. Contradicting the proposition of Kuzyakov et al. (2000), that states that the priming effect is dependent of the applied dose. This fact can be explained by the results of a latter study performed by Blagodatskaya and Kuzyakov (2008), whom shows that this dependence occurs only at dosages of applied organic matter up to $50 \%$ of soil microbial biomass. Considering that the microbial biomass represents $2 \%$ of soil organic C content (Paul \& Clark, 1989), all dosages applied were higher than this threshold. Thus, the Equation (7) should be valid only for smaller dosages of organic compost. For higher dosages, is proposed at the present study that this interaction be quantified by a constant identified as priming (pr) that multiply the kls and the krs value when the organic compost is applied. This operation allows proportional increase to its size and the decomposition rate of both pools of the native soil organic matter (Equation 8). 


$$
C_{o}=C_{l s} e^{-k_{l} p r t}+C_{r s} e^{-k_{r} p r t}+C_{p c} e^{-k_{p c} t}+C_{d c} e^{-k_{d c} t}
$$

Where, $\mathrm{pr}=$ priming effect, used only when the organic compost is applied to the soil.

The model was fitted to the experimental data, resulting in values of Cls equal to $2.02564 \mathrm{~g} \mathrm{~kg}^{-1}$, kls equal to $0.15711 \mathrm{dia}^{-1}$, Crs equal to $11.137 \mathrm{~g} \mathrm{~kg}^{-1}, \mathrm{krs}$ equal to $0.00147 \mathrm{~g} \mathrm{~kg}^{-1}, \mathrm{kpc}$ equal to $0.01179 \mathrm{dia}^{-1}$ and $\mathrm{C}_{\mathrm{pc}}$ equal to $1.465 \mathrm{~g} \mathrm{~kg}^{-1}$ with a $\mathrm{R}^{2}$ equal to 0,98 . A pr value of 1.098 shows that decomposition of native soil organic matter was accelerated in $9.8 \%$ when the organic compost was applied. Thus, it was possible to estimate the decomposition coefficient of the organic compost, which presented a $\mathrm{k}$ value of $0.01179 \mathrm{day}^{-1}$, at $31^{\circ} \mathrm{C}$ without water stress. Based on this model, at the end of 126 incubation days, the priming effect was responsible for the emission of $0.167 \mathrm{~g} \mathrm{~kg}^{-1}$ of $\mathrm{C}-\mathrm{CO}_{2}$ of the native soil organic matter, independent of the applied compost dose (Figure 3). At treatments 0.182 and $1.454 \mathrm{~g} \mathrm{~kg}^{3}$, the emission of $\mathrm{C}-\mathrm{CO}_{2}$ derived from organic compost was 0.142 and $1.133 \mathrm{~g} \mathrm{~kg}^{-1}$, respectively. It confirms the hypothesis that the overestimation of the $\mathrm{k}$ value is higher at lower doses, since the participation of the $\mathrm{C}-\mathrm{CO}_{2}$ emission due the priming effect is proportionally higher at lower dosages.
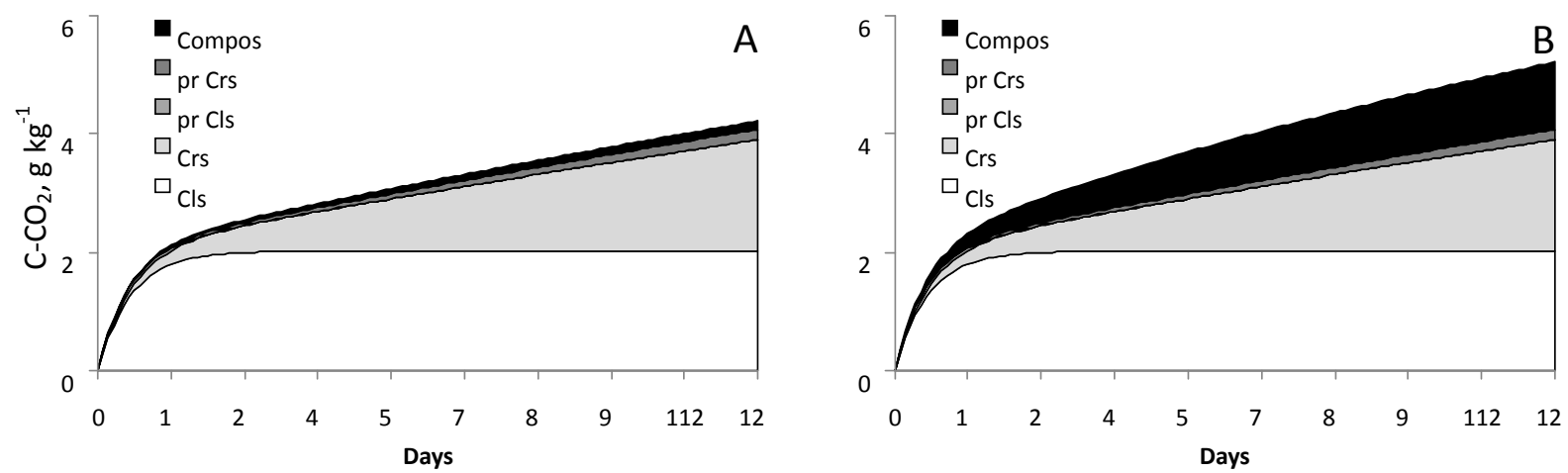

Figure 3. Estimated $\mathrm{C}-\mathrm{CO}_{2}$ emission from compost, from priming effect on recalcitrant soil organic matter (pr $\mathrm{C}_{\mathrm{rs}}$ ), from priming effect on labile soil organic matter $\left(\mathrm{pr} \mathrm{C}_{\mathrm{ls}}\right)$, from recalcitrant soil organic matter $\left(\mathrm{C}_{\mathrm{rs}}\right)$ and from labile soil organic matter $\left(\mathrm{C}_{\mathrm{ls}}\right)$. (A) $0.182 \mathrm{~g} \mathrm{~kg}^{-1}$ added compost and (B) $1.454 \mathrm{~g} \mathrm{~kg}^{-1}$ added compost

\section{Conclusion}

Organic compost produced using carcasses, sheepfold residues and slaughterhouse residues presented a $\mathrm{k}$ value equal to 0.01179 day $^{-1}$ at $31{ }^{\circ} \mathrm{C}$ without water stress. And application of this compost increased in $9.8 \%$ the decomposition rate of native soil organic matter.

Accounting of the priming effect as a constant that modify the decomposition rate of native soil organic matter proved appropriate to explain the interactions of the soil with the applied organic material. Using this model enables to estimate the $\mathrm{k}$ value of organic compost with higher precision, isolated of interaction with soil. It is suggested the employment of the present model, or other model that consider the interactions of the applied organic material with the soil in all studies related with the determination of $\mathrm{k}$ values of added organic material. Thus, in the future it will be possible to build a data set with the k values, intensity of the priming effect and protection capacity of a range of organic materials and soils. It will enable a wider range of practical application of these experimental results.

\section{Acknowledgements}

This work was supported by the Coordenação de Aperfeiçoamento de Pessoal de Nível.

Superior (CAPES) and Fundação Cearense de Apoio ao Desenvolvimento Científico e Tecnológico (Funcap).

\section{References}

Abreu, M. F., Andrade, J. C., \& Falcão, A. A. (2006). Chemical analysis protocols. In J. C. Andrade, \& M. F. Abreu (Eds.), Chemical analysis of solid waste for monitoring and agri-environmental studies (pp. 121-158). Campinas: Instituto Agronômico.

Alves, V. M. C., Vasconcellos, C. A., Freire, F. M., Pitta, G. V. E., França, G. E., Rodrigues Filho, A., ... Loureiro, J. E. (1999). Corn. In A. C. Ribeiro, P. T. G. Guimarães, \& V. V. H. Alvarez (Eds.), Soil fertility recommendations for Minas Gerais State (5 $5^{\circ}$ Approximation, p. 314). Soil fertility commission of Minas 
Gerais State.

Berg, B., \& McClaugherty, C. (2008). Plant litter. Decomposition, humus formation, carbon sequestration (2nd ed.). Springer-Verlag, Berlin, Germany. https://doi.org/10.1007/978-3-540-74923-3

Berge, A. C. B., Glanville, T. D., Millner, P. D., \& Klingborg, D. J. (2009). Methods and microbial risks associated with composting of animal carcasses in the United States. Journal of the American Veterinary Medical Association, 234(1), 47-56. https://doi.org/10.2460/javma.234.1.47

Bernal, M. P., \& Kirchmann, H. (1992). Carbon and nitrogen mineralization and ammonia volatilization from fresh, aerobically and anaerobically treated pig manure during incubation with soil. Biology and Fertility of Soils, 13(3), 135-141. https://doi.org/10.1007/BF00336268

Blagodatskaya, E., \& Kuzyakov, Y. (2008). Mechanisms of real and apparent priming effects and their dependence on soil microbial biomass and community structure: Critical review. Biology and Fertility of Soils, 45(2), 115-131. https://doi.org/10.1007/s00374-008-0334-y

Blum, B. (1992). Composting and the Roots of Sustainable Agriculture. Journal of Agriculture History, 66(2), 171-188.

Boyle, M., \& Paul, E. A. (1989). Carbon and nitrogen mineralization kinetics in soil previously amended with sewage sludge. Soil Science Society of America Journal, 53(1), 99-103. https://doi.org/10.2136/sssaj1989. $03615995005300010018 x$

Cayuela, M. L., Sinicco, T., \& Mondini, C. (2009). Mineralization dynamics and biochemical properties during initial decomposition of plant and animal residues in soil. Applied Soil Ecology, 41(1), 118-127. https://doi.org/10.1016/j.apsoil.2008.10.001

Demetz, M., \& Insam, H. (1999). Phosphorus availability in a forest soil determined with a respiratory assay compared to chemical methods. Geoderma, 89(3-4), 259-271. https://doi.org/10.1016/S0016-7061(98) 00090-1

Fangueiro, D., Ribeiro, H. M., Vasconcelos, E., Coutinho, J., \& Cabral, F. (2012). Influence of animal slurries composition and relative particle size fractions on the $\mathrm{C}$ and $\mathrm{N}$ mineralization following soil incorporation. Biomass and Bioenergy, 47, 50-61. https://doi.org/10.1016/j.biombioe.2012.10.003

Garcia-Pausas, J., Casals, P., Camarero, L., Huguet, C., Thompsone, R., Sebastia, M. T., \& Romanya, J. (2008). Factors regulating carbon mineralization in the surface and subsurface soils of Pyrenean mountain grasslands. Soil Biology \& Biochemistry, 40(11), 2803-2810. https://doi.org/10.1016/j.soilbio.2008.08.001

Hébert, M., Karam, A., \& Parent, L. E. (1991). Mineralization of nitrogen and carbon in soils amended with composted manure. Biological Agriculture \& Horticulture, 7(4), 349-361. https://doi.org/10.1080/ 01448765.1991 .9754565

Jenkinson, D. S., Andrew, S. P. S., Lynch, J. M., Goss M. J. D. S., \& Tinker P. B. (1990). The Turnover of Organic Carbon and Nitrogen in Soil. Philosophical Transactions of the Royal Society B, 329(1255), 361-368. https://doi.org/10.1098/rstb.1990.0177

Jin, V. L., Haney, R. L., Fay, P. A., \& Polley, H. W. (2013). Soil type and moisture regime control microbial C and $\mathrm{N}$ mineralization in grassland soils more than atmospheric $\mathrm{CO}_{2}$-induced changes in litter quality. Soil Biology \& Biochemistry, 58, 172-180. https://doi.org/10.1016/j.soilbio.2012.11.024

Kätterer, T., Reichstein, M., Andrén, O., \& Lomander, A. (1998). Temperature dependence of organic matter decomposition: A critical review using literature data analyzed with different models. Biology and Fertility of Soils, 27(3), 258-262. https://doi.org/10.1007/s003740050430

Kuzyakov, Y., Friedel, J. K., \& Stahr, K. (2000). Review of mechanisms and quantification of priming effects. Soil Biology \& Biochemistry, 32, 1485-1498. https://doi.org/10.1016/S0038-0717(00)00084-5

Lehmann, J. (2013). Recycle waste for nourishing soils. Nature, 504(7478), 33. https://doi.org/10.1038/504033b

Lousier, J. D., \& Parkinson, D. (1976). Litter decomposition in a cool temperate deciduous forest. Canadian Journal of Botany, 54(5-6), 419-436. https://doi.org/10.1139/b76-041

Marstorp, H., \& Kirchmann, H. (1991). Carbon and nitrogen mineralization and crop uptake of nitrogen from six green manure legumes decomposing in soil. Acta Agriculturae Scandinavica, 41(3), $243-252$. https://doi.org/10.1080/00015129109439906

Noble, R., \& Roberts, S. J. (2004). Eradication of plant pathogens and nematodes during composting: A review. 
Plant Pathology, 53(5), 548-568. https://doi.org/10.1111/j.0032-0862.2004.01059.x

Olson, J. S. (1963). Energy storage and the balance of producers and decomposers in ecological systems. Ecology, 44(2), 322-331. https://doi.org/10.2307/1932179

Orrico, A. C. A., Lucas Júnior, J., \& Orrico Júnior, M. A. P. (2007). Characterization and anaerobic digestion of goat manure. Engenharia Agrícola, 27(3), 639-647. https://doi.org/10.1590/S0100-69162007000400006

Paul, E. A., \& Clark, F. E., (1989). Soil Microbiology and Biochemistry. Academic Press, San Diego.

Shen, J., \& Bartha R., (1996). Priming Effect of Substrate Addition in Soil-Based Biodegradation Tests. Applied and Environmental Microbiology, 62(4), 1428-1430.

Six, J., Conant, R. T., Paul, E. A., \& Paustian, K. (2002). Stabilization mechanisms of soil organic matter: Implications for C-saturation of soils. Plant and Soil, 241(2), 155-176. https://doi.org/10.1023/A:1016125 726789

Van Veen, J. A., \& Paul, E. A. (1981). Organic carbon dynamics in grassland soils. 1. Background information and computer simulation. Canadian Journal of Soil Science, 61(2), 185-201. https://doi.org/10.4141/ cjss81-024

Waldrop, M. P., \& Firestone, M. K. (2004). Microbial community utilization of recalcitrant and simple carbon compounds: Impact of oak-woodland plant communities. Oecologia, 138(2), 275-284. https://doi.org/ 10.1007/s00442-003-1419-9

Zhang, Y., Lashermes, G., Houot, S., Doublet, J., Steyer, J. P., Zhu, Y. G., ... Garnier, P. (2012). Modelling of organic matter dynamics during the composting process. Waste Management, 32(1), 19-30. https://doi.org/ 10.1016/j.wasman.2011.09.008

\section{Copyrights}

Copyright for this article is retained by the author (s), with first publication rights granted to the journal.

This is an open-access article distributed under the terms and conditions of the Creative Commons Attribution license (http://creativecommons.org/licenses/by/4.0/). 